Langer and Quincke, of an entirely new and altogether unlooked-for group of chemical compounds, now known as the metallic carbonyls, is an admirable illustration of this faculty. The formation of nickel carbonyl-a most interesting substance produced by the direct combination of carbon monoxide with nickel -led to the establishment by him of a new process for the extraction of the metal from its ores which is now in successful operation by the Mond Nickel Company at Swansea.

Dr. Mond was a well-read man of liberal culture and artistic tastes, broad-minded and tolerant, and of a judgment ripened by contact with leading men of all conditions and countries. His merits as a man of science and a technologist were widely recognised. $\mathrm{He}$ was an honorary graduate of universities at home and abroad; a Fellow of the Royal Society, and a member of the Accademia dei Lincei. He was president of the Society of Chemical Industry in 1889 , and of the chemical section of the British Association in 1896 . He was offered the presidency of the Chemical Society a year or so ago, a distinction he was unable to accept owing to the state of his health.

He died on December II, I909, in the seventy-first year of his age, and was buried at the St. Pancras Cemetery, East Finchley.

T. E. Thorpe.

We have received the following short statement of generous assistance afforded by Dr. Mond to the progress of science, in addition to the foundation and endowment of the Davy-Faraday Research Laboratory, of which we hope to give an account in another issue.

Dr. Mond did not restrict his benefactions in science to the direct encouragement of physical and chemical researches. He was an original member of the council of the British Institute of Preventive Medicine (which subsequently developed into the Lister Institute), and gave $2000 l$. towards its foundation in 1893 . $\mathrm{He}$ also, three years ago, furnished $500 \mathrm{l}$. for installing an apparatus for the investigation of caisson disease and of the problems of deep-sea diving. The work in connection with this investigation was carried on by Drs. Haldane and Boycott, and Lieut. Damant, and their results were published in the Journal of Hygiene, and in a report to the Admiralty. At Dr. Mond's suggestion, and with the aid of a subsidy from him, a research into the toxicology of nickel carbonyl, a substance he had himself discovered and put to practical use in the manufacture of pure nickel, was carried out by $\mathrm{H}$. W. Armit, who published the results in two papers in the Journal of Hygiene.

In the year 1904 Dr. Mond contributed Io,0oo lire towards the cost of erecting a laboratory and hostel at Col d'Olen in connection with the International Laboratory of Physiology on Monte Rosa, on the understanding that the Royal Society should have the permanent nomination to two posts in the laboratory.

Shortly after his election into the Royal Society in I89 I, he gave practical effect to the deep interest which he felt in scientific bibliography. Indeed, but for his generous and active cooperation it would probably have been impossible for the Royal Society to continue its great undertaking of publishing a catalogue and index of the scientific literature of the last century.

In the second year of his fellowship of the Society Dr. Mond made a donation of $2000 l$. towards the cost of preparing the remaining material of the Catalogue and Subject Index of Scientific Papers, of which the third series was then approaching completion; and at the same time gave a promise of further assistance. This promise was amply fulfilled. Ten years later, in 1902, when the task of dealing with the mass of material published in the last seventeen years of the nineteenth century had to be faced, Dr. Mond offered $6000 l$. in four yearly instalments of $\mathrm{I}_{500 l}$. for the purpose of the completion of the catalogue and of the index. Again, in Igo6, on the expiry of the four years, he gave a further $6000 l$. in three yearly instalments of $2000 l$. each for the same purpose; and, towards the end of the year I908, he promised an additional donation of $2000 l$., with the view of accelerating the publication of the catalogue, and more particularly of the three subject-index volumes for mechanics, physics, and chemistry.

Dr. Mond also took an active part in the inauguration of the International Catalogue of Scientific Literature, now in its seventh year of publication, and his interest in that undertaking continued unabated to the end of his life.

\section{SIR ALFRED JONES, K.C.M.G.}

$\mathrm{O}^{\mathrm{F}}$ all the "slings and arrows of outrageous fortune," I have not of ten experienced one sharper than the news of the death of Sir Alfred Jones. I am not sure that, broadly looked at, the loss of a battle would not have been more tolerable. For a defeat may be retrieved, but the loss of a commander may be irremediable.

This is to rate his loss pretty high, but not, I think, too much so. For the man was of a quality of which I have not met with the like in the past, nor do I expect to do so in the future. I cannot pretend that I knew him intimately, for he was of that Napoleonic sort which does not invite intimacy. But we were brought together by common interest in public work, where we each strove strenuously by different paths, and where success attended Jones more than could have been hoped for.

Part of the story is told admirably by a sympathetic hand in the Times. If I lift the veil a little further, the official indiscretion, if it be such, must be condoned in justice to Jones's memory. An old-fashioned firm, Elder, Dempster and Co. were the shipping agents of Kew in Liverpool. They carried on the trade with the West African colonies which has always been centred there; and in this firm Jones was originally a clerk.

But at the start these colonies were mere trading settlements on the coast which no one at home troubled about so long as they did not trouble. Then came the partition of Africa; the hinterlands were brought under British control, and a new problem immediately arose. If tribal wars are to cease, and an orderly government is to be maintained, a revenue to support it must be raised; and in the last resort this can only be achieved by the promotion of native agriculture and the supply of produce for an export trade.

With these ends in view, Kew succeeded in establishing a number of cheap botanical stations, where plants suitable for cultivation could be grown and propagated, and where the natives could learn cultural methods by inspection. The attempt, for the most part, was rather acquiesced in than encouraged by the colonial officials on the spot, and Jones was perhaps the first to impress spontaneously upon the Colonial Office its importance. He had by that time grasped the future of West Africa, had bought out his old masters, and placed West African trade on an entirely new footing. Incidentally he restored prosperity to the Canaries, and introduced the banana into England. Amongst the principal products of West Africa are various sorts of oil-seeds; for these Liverpool was hardly more than an entrepot, as their principal market was in France. To utilise them at home, Jones started large oil-mills, All this, so far

NO. 2095, VOL. 82] 
as it goes, only reveals the enterprise and sagacity of a far-seeing man of business; but his subsequent work for the West Indies shows a different side to his character.

The sugar-bounty system had crippled the sugarindustry in the West Indies, and there was much distress amongst the planters and population. In 1896 Mr. Chamberlain sent out a Royal Commission to report on the position, and I willingly assented to the Assistant Director, now Sir Daniel Morris, accompanying it as scientific adviser. I sat one evening under the gallery of the House of Commons to hear Mr. Chamberlain make an eloquent appeal for a subsidy in aid of the distressed colonies. It was passed without demur. But something more than temporary aid was needed, and in 1898 Morris left Kew on his appointment as Imperial Commissioner of Agriculture in the West Indies. On the eve of his departure, happening to be at the Colonial Office, I was told that it was desired to get in touch with Alfred Jones. At that time I had never even seen him, but I invited him by telegraph to meet Morris and the Colonial Office men at dinner. That night the Direct Line was virtually agreed upon. As Jones left he remarked to me that the dinner had only cost him a quarter of a million. Later on he wrote that he was having steamers built in every available yard in the kingdom. At a semi-official gathering this year, the last time I saw him, Jones remarked that the dinner was still not paid for. But throughout his object was not limited to commercial success. He wanted to do for the West Indies what he had done for the Canaries. Morris, by botanical stations and agricultural instructors, sought to turn the negroes into peasant cultivators; Jones to provide an outlet for the produce. But he did much more, and in order to attract tourists he took the defunct hotel industry in Jamaica into his own hands.

Jones was, of course, a man of business, but in no ordinary sense. Commercial success was necessary to him as a justification of his plans, but I think still more as supplying means for extending them. It is no affectation to say that he, of all men, thought imperially. To knit the interests of the home country, and not least of Liverpool, with those of our colonial possessions was the real aim of his life. He offered the Rhodes scholars a free passage from any port at which his ships were available, and one of his latest schemes was to send out parties of undergraduates to make the personal acquaintance of the West Indies. On his last visit to them he took out a large number of distinguished guests. The event was tragic: in the earthquake Sir James Ferguson was killed in the street, and Jones himself was only extrin cated from the ruins of a falling hotel by little short of a miracle. It may be feared that the strain and shock left effects which were unperceived at the time.

But two other even greater achievements must be mentioned. In $1890-1 \mathrm{I}$ had succeeded in getting the cultivation of cotton experimentally tested in West Africa, and had had samples grown there valued at Manchester. But there the thing ended; it required a more vigorous impulse than mere demonstration. Jones habitually projected his ideas into the future. He saw that cotton-growing in the United States was limited by physical conditions, and could not be extended; that Indian cotton, for reasons too long to explain, was not available; and that the amount which the United States could spare must be a constantly diminishing quantity. He saw that fresh and independent supplies must be found. He virtually started the British Cotton-growing Association, and helped it to raise large funds, amounting to some quarter of a million. Jones possessed the electric power of stimulating more sluggish temperaments. With NO. 2095, VOL. 82]
Morris's aid, cotton-growing was successfully re-established in the West Indies. Jones pushed it for all he was worth in West Africa, and Northern Nigeria promises to be the greatest cotton-growing area in the world.

The importance of this achievement, however, shrinks before that which was perhaps the most remarkable of all. So far as I know, Jones had no scientific training; but he had a fixed belief in the value of scientific knowledge. There are plenty of business men who are ready, so to speak, to pluck the pear when it is ripe, careless who grew it. But Jones looked confidently to scientific method to help on the solution of unsolved problems. If commerce was to be carried on with tropical countries, it must be possible for Europeans to live in them. From his point of view it was not sufficient to treat the local diseases; it was necessary to trace them to causes which could be obviated. He therefore, in perfectly simple faith, founded and endowed the Liverpool School of Tropical Medicine, and sent out one scientific expedition after another to investigate on the spot. Cattle rearing in the West Indies is hampered by diseases which are transmitted by "ticks." Jones sent out Prof. Newstead to study their life-history; he saw that if you could control the tick you could master the disease. But you cannot control the tick until you know everything about it. I could give a striking illustration of a more futile procedure by our own Board of Agriculture.

Jones had, in fact, the true scientific instinct. $\mathrm{He}$ knew nothing about science, but he thoroughly believed in the validity of its methods. It is for this reason that he deserves commemoration in these pages. There are probably men like him in America; they are certainly rare in this country; Mond may have been one, but then he was not of English birth.

As I have said, I did not know Jones intimately, and I have therefore been able to write of what he did only as I saw it from outside. He lived a strenuous life, and was a man of few words. The Times speaks in terms which I can woll believe of his private generosity. I wrote to him on behalf of an orphan boy of promise in the village from which I write. Jones would promise nothing; but the boy got the post he desired in the engine-room of one of his ships.

Jones was a Welshman, and therefore, I suppose, a Celt. Perhaps to this he owed the buoyant optimism and that quality of imagination which is the primary element of success in science as in business. The great enterprises which he started probably possess sufficient momentum to continue; but the resourceful directing spirit is extinguished, and it is a national loss. He was not without honours amongst his own people in Lancashire. In IgoI he was created K.C.M.G. for his colonial services. But the distinction he most deeply prized was his election, without academic standing, as an honorary fellow of Tesus College, Oxford, a recognition which scarcely honoured the electors less than the recipient.

\section{W. T. Thiselton-Dyer.}

\section{NOTES.}

WE regret to announce the death, on December 18 , at Weybridge, of Dr. Shelford Bidwell, F.R.S., in his secondsecond year.

THE council of the Linnean Society has decided to devote the next meeting, on January 20 , to a discussion on the origin of vertebrates, in which it is expected that Dr. Gaskell, Dr. Gadow, Mr. Goodrich, Prof. Starling, Prof. MacBride, Dr. Smith Woodward, and Prof. Dendy will take part. 